\title{
The Effects of Entrepreneurship Orientation, Government Support and Internationalization on Malaysian SMEs Performance
}

\author{
Mohd Roslan Ismail and Zukarnain Zakaria
}

To Link this Article: http://dx.doi.org/10.6007/IJARBSS/v8-i7/4387

DOI: $\quad 10.6007 /$ IJARBSS/v8-i7/4387

Received: 04 June 2018, Revised: 26 June 2018, Accepted: 16 July 2018

Published Online: 29 July 2018

In-Text Citation: (Ismail \& Zakaria, 2018)

To Cite this Article: Ismail, M. R., \& Zakaria, Z. (2018). The Effects of Entrepreneurship Orientation, Government Support and Internationalization on Malaysian SMEs Performance. International Journal of Academic Research in Business and Social Sciences, 8(7), 453-468.

\section{Copyright: (C) 2018 The Author(s)}

Published by Human Resource Management Academic Research Society (www.hrmars.com)

This article is published under the Creative Commons Attribution (CC BY 4.0) license. Anyone may reproduce, distribute, translate and create derivative works of this article (for both commercial and non-commercial purposes), subject to full attribution to the original publication and authors. The full terms of this license may be seen at: http://creativecommons.org/licences/by/4.0/legalcode

\section{Vol. 8, No. 7, July 2018, Pg. 453 - 468}

Full Terms \& Conditions of access and use can be found at http://hrmars.com/index.php/pages/detail/publication-ethics 


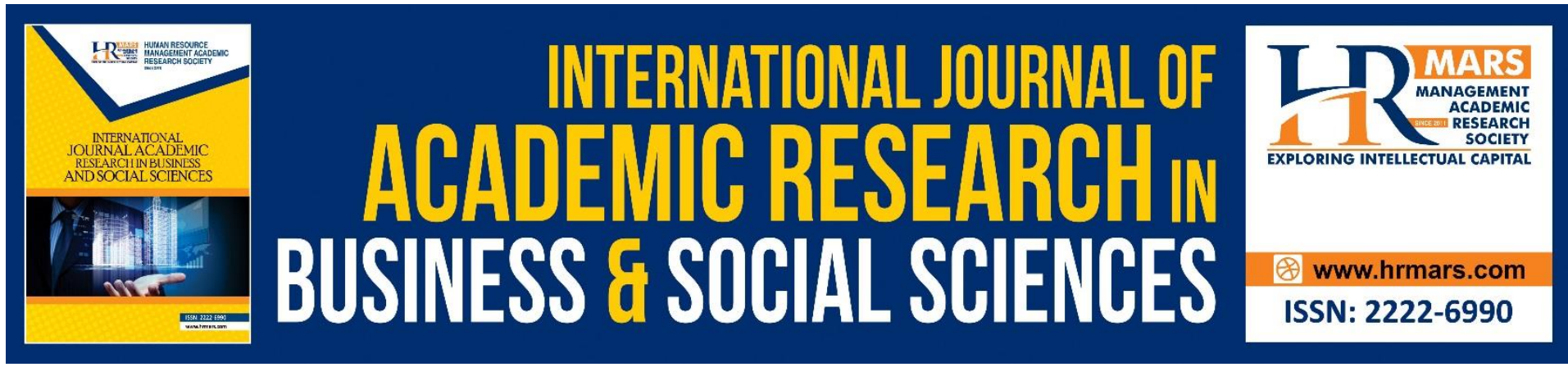

\title{
The Effects of Entrepreneurship Orientation, Government Support and Internationalization on Malaysian SMEs Performance
}

\author{
Mohd Roslan Ismail ${ }^{1}$ and Zukarnain Zakaria ${ }^{2}$ \\ ${ }^{1}$ Faculty of Business and Law, International University of Malaya-Wales \\ ${ }^{2}$ Malaysia-Japan International University of Technology, Universiti Teknologi Malaysia
}

\begin{abstract}
Prior studies on small and medium sized enterprises (SMEs) in Malaysia have focused on performance with inconclusive results. This paper contributes to the literature by examining variation in performance resulting from the synergistic role of entrepreneurial orientation, government support and internalization. It primarily explores three main industries: manufacturing, service and agriculture, generating data from 218 self-administered questionnaires. Using the Partial Least Squares (PLS) regression in testing the proposed hypothesis, it was uncovered that the mediating effect of internationalization between entrepreneurship orientation and firm performance was insignificant. In contrast, Government support was seen as a stronger predictor of firm performance. Furthermore, internationalization was shown to only partially mediate government support and firm performance. This study emphasizes the importance of Government support and will aid stakeholders in developing a robust understanding of the role of key factors in shaping SME performance in the global market.
\end{abstract}

Keywords: Entrepreneurship Orientation, Government Support, Internationalization, SMEs Performance

\section{Introduction}

The role of small and medium sized enterprises (SMEs) is more important in developing countries than developed countries, as SMEs are an important vehicle for economic development. Despite this, SME failures and collapses still take place and problems prevail. For example, Malaysian SME failure rates which are recorded at 60 percent, is considered to be disturbingly high $\mathrm{N}$. H. Ahmad and Seet (2009) when compared to Australia, for example, where failure is measured at $23 \%$. Jamak, Salleh, Sivapalan, and Abdullah (2012) indicated that only 10 percent of SMEs were still operating after 10 years, with many failing within the first five years of operation (Jaafar, A.R Abdul-Aziz, Maideen, \& Mohd, 2011). Consequently, only a handful of the large number of start-up businesses survive and grow into successful firms (Cassar, 2006).

SMECorp (2012) conducted a survey of Malaysian SMEs and reported that they are less likely to grow beyond the current size. The finding showed about 14 percent of the SMEs did expand during the survey period, while 16 percent closed down and another 14 percent experienced reductions in 
size. Consistent with the SMECorp (2012), the ASEAN SME policy (2014) stated that a major problem experienced by SMEs stems from their size, with regard to rapid trade liberalization. Consequently, it must be emphasized that to reap the benefits of globalization and regional trading, SMEs need to adapt and make changes to their internal organization. Moreover, in order to be competitive and sustainable, Malaysian SMEs have to strive for the export markets (MATRADE, 2017).

Firms gradually build experience and expand into overseas markets. The choice of whether to expand internationally is a vital decision for SMEs who are essentially limited in funds and are domestically focused (Barringer \& Greening, 1998). Abdullah and Zain (2011) observed that internationalization can have lasting impact on Malaysia SMEs such as 1) increasing profit, 2) creating new market opportunities, 3) expanding business and marketing and 4) motivating entrepreneurs.

Yet, Malaysian SMEs involvement in the international is still considered low. This largely stems from the SMEs' limited entrepreneurial direction. Based on SMECorp (2012), Malaysian SMEs' contribution is still underrepresented in terms of export (19\%) as compared to developed countries, where export contributions, on average, are 50\%. Reports suggest that Malaysian SMEs are reluctant risk-takers, lack innovativeness, and not up to aggressive competition.

There is a marked difference between the strategies adopted by developed and newer economies in their internationalization efforts. American SMES, for example, are more reactive in their approach, focusing on international opportunities and cutting-edge R\&D (Karagozoglu \& Lindell, 1998). In contrast, newer economies as in Malaysia, rely on proactive approaches. As Che Senik, Mat Isa, Sham, and Ayob (2014) observed, Malaysian SMEs were largely motivated by government intervention with regard governance, international business policies, custom procedures, subsidies and incentives (Mtigwe, 2005; Root, 1994).

The objective of this paper is to build on the literature by evaluating the link between and influence of entrepreneurial orientation, government support, and internationalization on performance amongst SMEs in Malaysia. The results hold implications especially for SME entrepreneurs intending to venture internationally, and for the government in addressing awareness and motivation amongst SMEs so they may fully exploit the international opportunities.

\section{Literature Review}

This section discusses the theoretical foundations, and review related empirical studies. Using the literature on entrepreneurial orientation, government support and internalization on the firm performance, a theoretical model of the study will be presented at the end of this section.

The entrepreneurial orientation construct has achieved prominence in internationalization and entrepreneurship literature (Huang, Wang, Tseng, \& Wang, 2010; Ibeh \& Young, 2001). Originating from the seminal research by Mintzberg (1973), it emphasizes the characteristics of entrepreneurial firms as being more inclined towards risk-taking, besides being more aggressive in seeking new opportunities. Specifically, Miller (1983), described the three characteristics of entrepreneurial orientation that have been identified and used regularly in the literature; innovativeness, proactiveness and risk-taking.

The critical role played by innovativeness in international entrepreneurship research S. Zahra, Hayton, and Salvato (2004) highlights its positive influence on the performance of SMEs that have ventured overseas Knight and Cavusgil (2004). Through innovativeness, newer firms are able to 
compete with and survive against larger and more established multinationals (MNEs) (Deshpandé, Grinstein, Kim, \& Ofek, 2013).

Proactiveness and reactiveness are distinct, in that proactiveness emphasizes aggressiveness, taking quick action and pursuing them to achieve the stated objectives of the firm, especially in the face of competition. In other words, it requires that entrepreneurs have a vision of future direction, and are able to exploit business opportunities without advanced planning. In Tsang (2002) study, of Chinese family enterprises, he observed that a crucial element of proactive firms is the visionary and practical steps taken by leaders who aggressively seek resources and market opportunities in international markets.

Additionally, how entrepreneurs respond risks is equally important (Busenitz, 1999). The two types of risks mentioned by Casson and Wadeson (2007) are; missing a profitable opportunity (error of omission) and exploiting an unprofitable opportunity (error of commission). If SME owners are adept and able to avoid these risks, they can be successful at exploiting the various opportunities that internalization has to offer (Terjesen \& Elam, 2009).

Entrepreneurial orientation is seen as a significant factor influencing growth and profitability (Zainol \& Ayadurai, 2011). Thus, in a competitive business setting with shorter product and business life cycles, the importance of such characteristics in generating better performance cannot be underestimated. In sum, entrepreneurial orientation is an influential, critical factor that determines the success of a firm (Hamel, 2000).

The development and diversification of SMEs have been impacted by government promotional programs and the country's economic development (Tambunan, 2008). S. Z. Ahmad (2008), and S. Z. Ahmad and Kitchen (2008) claimed that various factors (e.g., government aid in firm expansion), together with the firm's technological and knowledge capabilities, have harnessed the competitive edge of Malaysian companies. The government's assistant (e.g for example support policies, support programs) (Smallbone \& Welter, 2001), monetary assistance and preferential treatment Spencer and Gomez (2004) can assist smaller firms in overcoming various challenges. Government support programs can also play an important role in the SMEs' internationalization process Shamsuddoha, Ali, and Ndubisi (2009), and entrepreneurial success (Spencer \& Gomez, 2004).

Hung, Lien, Yang, Wu, and Kuo (2011) stated that government support in Malaysia can improve SME performance. It is also the most effective factor in their success. Yet, as pointed out by Idris (2012), if there is too much government support, entrepreneurs lose their own power to control their direction and their belief in their own abilities, becoming too dependent on government intervention. This leads to entrepreneurial attitudes that are prone to blame other parties for their failure, lack of innovation and productivity.

Internationalization is a key determinant of the growth of firms (Abdullah \& Zain, 2011; Peng \& Delios, 2006), the solid reasons justifying internationalization being as follows; the self-interest of the organizations themselves, perceptions of being threatened in domestic environments, recognition of foreign business opportunities, and the impact of various external events and forces (Abdullah \& Zain, 2011; Scarborough, 2012). As S.A. Zahra, Korri, and Yu (2005) argued, the key reasons for undertaking overseas ventures include market expansion, higher financial gains and learning new ideas.

Calof and Beamish (1995) explained internationalization as "the process of adapting a firm's operation to international environments." Internationalization is an essential aspect of the firm growth to perform beyond their national borders, with sustainability in the global market place. It is also necessary that firms compete with other firms at national, industry and firm level (Chelliah, Sulaiman, \& Yusoff, 2010). SME internationalization, for example, developed from the availability of 
new markets that opened up through deregulation, and competition for such emerging markets (Matenge, 2011).

Hajela and Akbar (2013) and Contractor, Hsu, and Kundu (2005) uncovered an important link between internationalization and the performance of firms. Conversely, Saixing, Xie, Tam, and Wan (2009) indicated that the international expansion strategy serves as a vital and profitable source of growth although such ventures may also incur huge losses due to fierce global competition.

Internationalization performance has been analyzed from both financial and non-financial aspects. Despite the popularity of financial performance indicators, the link between internationalization and firm performance is still unclear. Consequently, current perspectives in measuring and understanding performance appear to be more focused on non-financial aspects (Stam, 2015).

Growth and profitability are performance elements that can be considered important consequences of firm performance. However, as the financial results of internationalization have proven to be unclear, Shaker A. Zahra and George (2002) argued for the use of both financial and non-financial measures in determining the performance outcomes of internationalization. Therefore, this study utilizes both indicators to measure firm performance. While financial performance is measured by return on equity, return on assets and sales growth, the indicators for non-financial-performance include competitive capability and technological learning.

Despite the importance of internationalization and the extensive scholarship committed to the field, empirical evidence on the direct effects of organizational and environmental characteristics and internationalization on firm performance has provided inconsistent results (Zahra \& George, 2002). Several studies support the direct impact effects of entrepreneurial orientation, government support, and internationalization on firm performance (Zainol \& Ayadurai, 2011; Kang \& Park, 2012). However, there are also studies found no empirical support for the direct impact of organizational characteristics and internationalization on firm performance.

Several studies have used internationalization as a mediator in the relationship between organizational and environmental characteristics and firm performance (Tanvisuth, 2007; Chelliah et al., 2010). This was augmented by Tavisuth's (2007) observation of small and medium enterprises in Thailand that internationalization tended to partially mediate the relationship between organizational characteristics and firm performance. Therefore, this study posits that these two factors are not independent of each other and that the relationship between organizational and environmental characteristics, and firm performance is mediated by internationalization.

Framework below (Figure 2.1) based on work of Antoncic and Hisrich (2001). Thus, the hypotheses of the study are:

$\mathrm{H} 1$ : Entrepreneurial orientation relates positively to internationalization

H2: Government support relates positively to internationalization

H3: Entrepreneurial orientation relates positively to firm performance.

H4: Government support relates positively to firm performance.

H5: Internationalization relates positively to firm performance.

H6: Internationalization mediates the relationship between entrepreneurial orientation and firm performance.

H7: Internationalization mediates the relationship between government support and firm performance. 
Figure 2.1: Theoretical Model

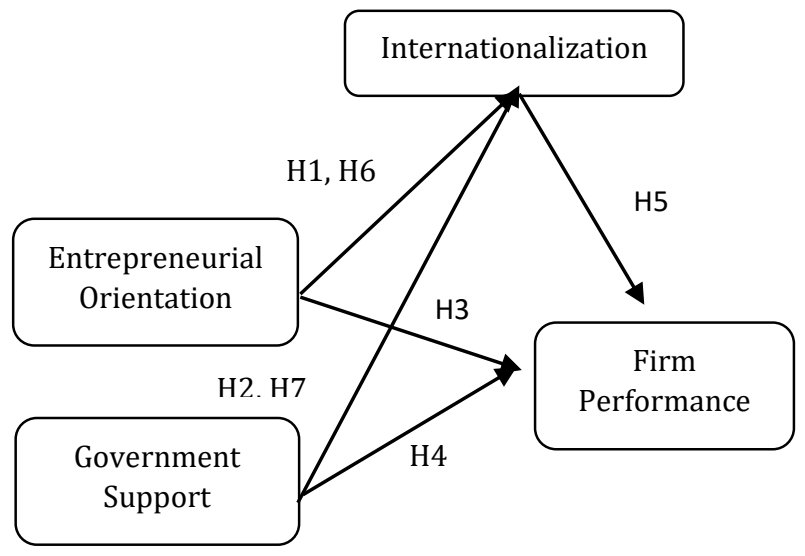

Source: Antoncic and Hisrich (2001)

\section{Research Design}

\section{A. Research Scope}

The research focused on Malaysian SMEs with international ventures in three main industries; manufacturing, service and agriculture. It involved newer and established firms, traditional, lowtechnology and high-technology industries in examining if the theories developed based on mature market contexts are also applicable to the emerging economies. The definition of SMEs provided by the National SME Development Council (NSDC, 2013) is used in this study, as follows:

- Manufacturing sector SMEs: Sales turnover not exceeding RM25 million or less than 150 fulltime employees;

- Services and other sectors SMEs: Sales turnover not exceeding RM5 million or less than 50 full-time employees.

\section{B. Sampling}

There are several methods to determine optimal sample size. Hair, Hult, Ringle, and Sarstedt (2014) stated that the rule of thumb for a minimum sample size should be ten times the maximum number of arrowheads pointing at a latent variable anywhere in the PLS path model as general guidelines. Another method to determine sample size is through statistical power test. High efficiency in parameter estimation and relationship significant can be gained from greater statistical power (Hair, Hult, et al., 2014).

To determine the sample size for this study, power of a test approach was a feasible option. G*Power 3.1.9.2 software was used to determine the sample size: 184 SMEs. Study respondents were SME owners, or the higher management executives of who have first-hand knowledge about their firms' characteristics, management styles, international strategies and performance.

\section{Measures}

Table 3 shows the sources for the measure of the constructs used in the investigation. The instrument uses a six-point Likert scale to measure each construct and the responses range from 1 (strongly disagree) to 6 (strongly agree). The use of this Likert scale benefits the respondents as it shorter and easier to use in completing the questionnaire. Hair, Sarstedt, Ringle, and Mena. (2012) emphasized that the need for a higher level of precision should be proportionate to the demands placed on respondents. 
Table 3: Constructs and Measures

\begin{tabular}{ll}
\hline Constructs & \multicolumn{1}{c}{ Sources } \\
\hline Entrepreneurial Orientation & Dickson and Weaver, 2008; Kreiser et al., 2002; Miller and \\
& Friesen, 1983 \\
Government Support & Smallbone and Welter, 2001; Abdullah, 1999; Doutriaux, \\
& $1998 ;$ \\
& Harrison and Mason, 1988 \\
& Lehtinen and Penttinen, 1999; Ahokangas, 1998; Johanson \\
& and Vahlne, 1990 \\
& Chiao, Yang and Yu (2004); Carayannis and Alexander, 2002; \\
Internationalization & Lu and Beamish (2001); Kogut and Zander,1992
\end{tabular}

Firm Performance

\section{Data analysis}

The Statistical Package Social Science for Windows version 21.0 was used for descriptive statistics and the two-step approach as recommended by (Anderson \& Gerbing, 1998). The measurement models are assessed for adequate validity and unidimensionality prior to the conduct of structural model effects and interaction modelling for hypotheses testing. Data analysis was performed using Partial Least Squared (PLS), a structural equation modelling technique using a component based approach. PLS affords several advantages; 1$)$ complex structural equation models with a large number of constructs with 50 or more items (Vinzi, Chin, Henseler, \& Wang, 2010); 2) suitable for theory development (new variables are added to the theory) rather than theory testing; 3 ) useful for prediction; and 4) does not need huge sample sizes as other casual modelling techniques (Urbach \& Ahlemann, 2010).

\section{Results}

\section{A. Descriptive statistics}

Table 4.1 summarizes the respondent profile. The majority of the sample were SMEs in the manufacturing sector (41.7\%), as compared to the service $(35.8 \%)$ and agriculture (22.5\%) sectors. The majority (58.7\%) of the respondents earned between RM10 million and RM25 million; this was followed by RM250 000 to RM9.9 million (28.9\%) and RM25 million and above (12.4\%). As for fulltime staff, the majority of the respondents sampled had 51 to 150 employees (58.3\%), as compared to 5 to 50 employees (32.1\%) or more than 150 employees (9.6\%).

Respondents were also asked to provide details regarding their company's head office location. The data revealed that more than half (59.2\%) were located in urban areas, while $33.0 \%$ were located in suburban and rural areas (7.8\%). The business status statistics showed that more than half of the respondents have Bumiputera status (60.1\%). In addition, for the form of ownership status, $77.1 \%$ of respondents were from a private limited company, while $11.5 \%$ were in a partnership or were a sole-proprietor. 
Table 4.1: Profile of Respondents

\begin{tabular}{|c|c|c|c|}
\hline \multirow{2}{*}{ Demographic } & \multirow{2}{*}{ Categories } & \multicolumn{2}{|c|}{ Total $(\mathrm{N}=\mathbf{2 1 8})$} \\
\hline & & No & $\%$ \\
\hline \multirow{3}{*}{ Sector } & Manufacturing & 91 & $41.7 \%$ \\
\hline & Services & 78 & $35.8 \%$ \\
\hline & Agriculture & 49 & $22.5 \%$ \\
\hline \multirow{3}{*}{$\begin{array}{l}\text { Total Annual } \\
\text { Sales }\end{array}$} & $\begin{array}{l}\text { More than } \\
\text { RM25million }\end{array}$ & 27 & $12.4 \%$ \\
\hline & $\begin{array}{l}\text { RM10 million - } \\
\text { RM25million }\end{array}$ & 128 & $58.7 \%$ \\
\hline & $\begin{array}{l}\text { RM250,000 - } \\
\text { RM9.9million }\end{array}$ & 63 & $28.9 \%$ \\
\hline \multirow{3}{*}{$\begin{array}{l}\text { Number of } \\
\text { full-time staff }\end{array}$} & $\begin{array}{c}\text { more than } 150 \\
\text { employees }\end{array}$ & 21 & $9.6 \%$ \\
\hline & $\begin{array}{c}51 \text { - } 150 \\
\text { employees }\end{array}$ & 127 & $58.3 \%$ \\
\hline & $\begin{array}{c}5 \text { - } 50 \\
\text { employees }\end{array}$ & 70 & $32.1 \%$ \\
\hline \multirow{3}{*}{$\begin{array}{l}\text { Location of } \\
\text { your } \\
\text { company's } \\
\text { head office }\end{array}$} & urban & 129 & $59.2 \%$ \\
\hline & sub-urban & 72 & $33.0 \%$ \\
\hline & rural & 17 & $7.8 \%$ \\
\hline \multirow{5}{*}{$\begin{array}{c}\text { Duration of } \\
\text { your } \\
\text { company's } \\
\text { international } \\
\text { experience }\end{array}$} & $2-5$ & 51 & $23.4 \%$ \\
\hline & $6-10$ & 59 & $27.1 \%$ \\
\hline & $11-15$ & 34 & $15.6 \%$ \\
\hline & $16-20$ & 23 & $10.6 \%$ \\
\hline & $21-25$ & 51 & $23.4 \%$ \\
\hline \multirow{3}{*}{$\begin{array}{l}\text { Form of } \\
\text { ownership } \\
\text { status }\end{array}$} & $\begin{array}{c}\text { sole- } \\
\text { proprietor }\end{array}$ & 25 & $11.5 \%$ \\
\hline & partnership & 25 & $11.5 \%$ \\
\hline & $\begin{array}{c}\text { private limited } \\
\text { company }\end{array}$ & 168 & $77.1 \%$ \\
\hline \multirow{2}{*}{$\begin{array}{l}\text { Business } \\
\text { status }\end{array}$} & Bumiputera & 131 & $60.1 \%$ \\
\hline & $\begin{array}{c}\text { non- } \\
\text { Bumiputera }\end{array}$ & 87 & $39.9 \%$ \\
\hline
\end{tabular}

\section{B. Partial Least Square Findings}

The PLS regression was applied to detect relationships among the constructs. Convergent validity measures the degree to which the items that are indicators of a specific construct converge or share a high proportion of variance in common. The loadings for all items should be beyond the recommended value of 0.50 or higher (Hair, Sarstedt, Hopkins, \& Kuppelwieser, 2014). The composite reliability (CR) of all constructs was above 0.6 (Bagozzi \& Yi, 1988), while the average variance extracted (AVE) was above 0.5 (Fornell \& Larcker, 1981), thus supporting the stated requirements. 
The AVE for this study is in the range of 0.520 and 0.882 . The composite reliability, which indicates the degree to which the latent variables can be explained by the observed variables (Ringle, Sarstedt, \& Straub, 2012), is in the range of 0.844 and 0.964 . This exceeds the cut off value of 0.6 (Bagozzi \& Yi, 1988), and hence, the composite reliability measurement is reliable. Thus, this study ensured the existence of convergent validity.

Table 4.2: Result of Measurement Model

\begin{tabular}{|c|c|c|c|c|}
\hline Model Construct & Items & Loading & CR & AVE \\
\hline \multirow[t]{5}{*}{ Innovative } & EO2 & 0.736 & 0.844 & 0.520 \\
\hline & EO3 & 0.760 & & \\
\hline & EO5 & 0.637 & & \\
\hline & EO7 & 0.701 & & \\
\hline & EO8 & 0.764 & & \\
\hline \multirow[t]{5}{*}{ Proactive } & EO11 & 0.733 & 0.907 & 0.663 \\
\hline & EO12 & 0.885 & & \\
\hline & EO13 & 0.880 & & \\
\hline & EO14 & 0.853 & & \\
\hline & EO16 & 0.702 & & \\
\hline \multirow[t]{4}{*}{ Risk Taking } & EO17 & 0.818 & 0.846 & 0.580 \\
\hline & EO18 & 0.824 & & \\
\hline & EO20 & 0.728 & & \\
\hline & EO22 & 0.665 & & \\
\hline \multirow[t]{4}{*}{ Funding } & GS1 & 0.812 & 0.924 & 0.753 \\
\hline & GS2 & 0.874 & & \\
\hline & GS3 & 0.899 & & \\
\hline & GS4 & 0.885 & & \\
\hline \multirow[t]{4}{*}{ Policies } & GS5 & 0.881 & 0.914 & 0.726 \\
\hline & GS6 & 0.902 & & \\
\hline & GS7 & 0.820 & & \\
\hline & GS8 & 0.801 & & \\
\hline \multirow[t]{4}{*}{ Contract } & GS9 & 0.874 & 0.930 & 0.770 \\
\hline & GS10 & 0.894 & & \\
\hline & GS11 & 0.829 & & \\
\hline & GS12 & 0.912 & & \\
\hline \multirow[t]{4}{*}{ Internationalization } & INT1 & 0.918 & 0.886 & 0.664 \\
\hline & INT2 & 0.887 & & \\
\hline & INT3 & 0.710 & & \\
\hline & INT4 & 0.722 & & \\
\hline \multirow[t]{3}{*}{ Financial } & FP1 & 0.942 & 0.957 & 0.882 \\
\hline & FP2 & 0.963 & & \\
\hline & FP3 & 0.911 & & \\
\hline \multirow[t]{11}{*}{ Non-Financial } & NFP1 & 0.811 & 0.964 & 0.710 \\
\hline & NFP2 & 0.605 & & \\
\hline & NFP3 & 0.835 & & \\
\hline & NFP4 & 0.780 & & \\
\hline & NFP5 & 0.852 & & \\
\hline & NFP6 & 0.886 & & \\
\hline & NFP7 & 0.868 & & \\
\hline & NFP8 & 0.896 & & \\
\hline & NFP9 & 0.906 & & \\
\hline & NFP10 & 0.876 & & \\
\hline & NFP11 & 0.904 & & \\
\hline
\end{tabular}

Note: EO1, EO4, EO6, EO9, EO10, EO15, EO19, EO21, EO23, E024, EO25 were deleted due to low loading 
Discriminant validity measures the distinctiveness of one construct to another (Hair, Hult, et al., 2014). It is illustrated via an inevitably low correlation between the measure of interest and other measures that are supposedly not measuring the same variable or concept (Ringle et al., 2012).

Table 4.3 (Appendix 1) illustrates that the calculated square root of the AVE exceeds the intercorrelations of the construct with the other constructs in the model, thus indicating adequate discriminant validity. In sum, the measurement model of the study demonstrated adequate convergent and discriminant validity.

Table 4.4 shows the theoretical model path results. The values stated on the path are path coefficients and t-values. About $38.7 \%$ of the variance, in extent of firm performance, was explained by the entrepreneurship orientation, government support and internationalization. Out of five direct effect hypotheses, four are significant at the $1 \%$. Surprisingly, there is no significant relationship between the entrepreneurial orientation and internationalization, as shown in Table 4.4 (Appendix 2).

In order to analyze higher order construct, it is important to provide information pertaining to selected modelling approach and reports for constructs properties (Hair, Sarstedt, et al., 2014). Furthermore, they suggest that analysis report for formative model should be included indicator outer weights and multicollinearity of indicators.

This study selects reflective-formative modelling approach that suit with the assessed constructs. At higher order construct level, 3 constructs namely entrepreneurship orientation, government support and firm performance were measured through formative model where 3 variables innovation, proactive and risk taking were conceptualized to form entrepreneurship orientation construct.

Furthermore, 3 variables as contract, funding and policies were conceptualized to form government support and lastly firm performance construct were conceptualized by 2 variables namely financial and non-financial.

Table 4.5: Assessment results of second order construct for formative

\begin{tabular}{llccc}
\hline FORMATIVE & Variable & $\begin{array}{c}\text { Outer } \\
\text { Weight }\end{array}$ & $\begin{array}{c}\text { Outer } \\
\text { Loading }\end{array}$ & VIF \\
\hline \multirow{2}{*}{$\begin{array}{llcl}\text { Entrepreneurship } \\
\text { Orientation }\end{array}$} & Innovative & 0.311 & 0.838 & 1.993 \\
& Proactive & 0.334 & 0.842 & 1.929 \\
& Risk & 0.490 & 0.936 & 2.625 \\
\hline \multirow{2}{*}{$\begin{array}{l}\text { taking } \\
\text { Suppornment }\end{array}$} & Contracts & 0.321 & 0.911 & 3.222 \\
& Funding & 0.341 & 0.919 & 3.337 \\
Performance & Policies & 0.411 & 0.960 & 4.862 \\
& Financial & 0.484 & 0.690 & 1.081 \\
& Non- & 0.753 & 0.885 & 1.081 \\
\hline
\end{tabular}

As shown in Table 4.5 (Appendix 3), there were no serious collinearity issues on these variables and all VIF results for all formative variables were within acceptable value. Meanwhile, the findings of mediation effect hypotheses was summarized in Table 4.6.

Hypotheses can be examined to see which are supported by the analysis. Table 4.7 presents the summary of hypotheses testing. The findings showed that 6 out of 7 hypotheses are supported, and only entrepreneurship orientation towards internalization is not significant. 
Table 4.7: Summarizes the summary of hypotheses testing

\begin{tabular}{clccc}
\hline \multicolumn{3}{c}{ Hypotheses } & Results \\
\hline H1 & $\begin{array}{l}\text { Entrepreneurial orientation relates positively } \\
\text { internationalization }\end{array}$ & with & Not Supported \\
\hline H2 & $\begin{array}{l}\text { Government support relates positively } \\
\text { internationalization }\end{array}$ & with & Supported \\
\hline H3 & $\begin{array}{l}\text { Entrepreneurial orientation relate positively with firm } \\
\text { performance }\end{array}$ & Supported \\
\hline H4 & $\begin{array}{l}\text { Government support relate positively with firm } \\
\text { performance }\end{array}$ & Supported \\
\hline H5 & $\begin{array}{l}\text { Internationalization relates positively with firm } \\
\text { performance }\end{array}$ & Supported \\
\hline H6 & $\begin{array}{l}\text { Internationalization mediates the relationship between } \\
\text { entrepreneurial orientation and firm performance }\end{array}$ & Not Supported \\
\hline H7 & $\begin{array}{l}\text { Internationalization mediates the relationship between } \\
\text { government and firm performance }\end{array}$ & $\begin{array}{c}\text { Supported } \\
\text { Partial Mediation }\end{array}$ \\
\hline
\end{tabular}

\section{Conclusion}

This study examined the determinants of internationalization. Specifically, it examined entrepreneurial orientation and government support as constructs and analysed their relationship with the internationalization of Malaysian SMEs. The analysis produced mixed results. Most of the firms involved in this study are relatively young ventures, aged below 10 years, with low involvement and commitment in international operations. Therefore, these SMEs are not highly entrepreneurially orientated and heavily depend on government support for their internationalization.

These observations lead to the conclusion that SMEs in Malaysia need to adopt a highly entrepreneurial approach and this can be developed through extensive entrepreneurial training and practical, real-life mentorships. The results of the study also highlight the advantages of SME internationalization such as their positive financial and non-financial performance development. Thus, these findings make it imperative for SMEs in Malaysia to open up their firms to international markets to increase revenue, besides experiencing growth and development in international markets.

Firms also need to have better understanding of the aspects of internationalization via qualitative and quantitative perspectives. The qualitative research provided a clearer understanding and made it possible to formulate better propositions, allowing firms to effectively carry out the said propositions.

\section{References}

Abdullah, N. A. H. N., \& Zain, S. N. M. (2011). The Internationalization Theory and Malaysian SmallMedium Enterprises (SMEs). International Journal of Trade, Economics and Finance, 4, 318-322. doi:10.7763/IJTEF.2011.V2.124

Ahmad, N. H., \& Seet, P. S. (2009). Dissecting behaviours associated with business failure: a qualitative study of SME owners in Malaysia and Australia. Asian Social Science,, 5(9), 98103.

Ahmad, S. Z. (2008). The Internationalization Process of Third World Multinational Firms: A Study of Malaysia's Government-linked Corporations. International Journal of Business Research, 8(5), 35-47. 
Ahmad, S. Z., \& Kitchen, P. J. (2008). Transnational corporations from Asian developing countries: The internationalisation characteristics and business strategies of Sime Darby Berhad. International Journal of Business Science and Applied Management, 3(2), 21-36.

Anderson, J. C., \& Gerbing, D. W. (1998). Structural Equation Modeling in Practice: A Review and Recommended Two-Step Approach. Psychological Bulletin, 103(3), 411-423.

Bagozzi, R. P., \& Yi, Y. (1988). On the evaluation of structural equation models. Journal of the Academy of Marketing Science, 16(1), 74-94.

Barringer, B. R., \& Greening, D. W. (1998). Small business growth through geographic expansion: A comparative case study. Journal of Business Venturing, 13(6).

Busenitz, L. W. (1999). Entrepreneurial Risk and Strategic Decision Making: It's a Matter of Perspective. Journal of Applied Behavioral Science, 35(3), 325-340.

Calof, J. L., \& Beamish, P. W. (1995). Adapting to foreign markets: Explaining internationalization. International Business Review, 4(2), 115-131.

Cassar, G. (2006). Entrepreneur opportunity costs and intended venture growth. Journal of Business Venturing, 21(5), 610-632.

Casson, M., \& Wadeson, N. (2007). The Discovery of Opportunities: Extending the Economic Theory of the Entrepreneur. Small Business Economics, 28(4), 285-300.

Che Senik, Z., Mat Isa, R., Sham, R., \& Ayob, A. (2014). A Model for Understanding SMEs Internationalization in Emerging Economies (Vol. 41).

Chelliah, S., Sulaiman, M., \& Yusoff, Y. M. (2010). Internationalization and Performance: Small and Medium Enterprises (SMEs) in Malaysia. International Journal of Business and Management, 5(6), 27-37.

Contractor, F. J., Hsu, C. C., \& Kundu, S. K. (2005). Explaining export performance: a comparative study of international new ventures in Indian and Taiwanese software industry. Management International Review, 45(3), 83-110.

Deshpandé, R., Grinstein, A., Kim, S. H., \& Ofek, E. (2013). Achievement motivation, strategic orientations and business performance in entrepreneurial firms: How different are Japanese and American founders? . International Marketing Review, 30(3), 231-252.

Fornell, C., \& Larcker, D. F. (1981). Evaluating structural equation models with unobservable variables and measurement error. Journal of Marketing Research, 18(1), 39-50.

Hair, Hult, G. T. M., Ringle, C. M., \& Sarstedt, M. (2014). A Primer on Partial Least Squares Structural Equation Modeling (PLS-SEM). Thousand Oaks: Sage.

Hair, Sarstedt, M., Hopkins, L., \& Kuppelwieser, V. G. (2014). Partial least squares structural equation modeling (PLS-SEM): An emerging tool in business research. European Business Review, 26(2), 106-121.

Hair, Sarstedt, M., Ringle, C. M., \& Mena., J. A. (2012). An Assessment of the Use of Partial Least Squares Structural Equation Modeling in Marketing Research. Journal of the Academy of Marketing Science, 40(3), 414-433.

Hajela, A., \& Akbar, M. (2013). Internationalisation of small and medium software firms from India. International Journal of Technological Learning, Innovation and Development, 6(1/2), 88101.

Hamel, G. (2000). Leading the revolution Boston, MA: Harvard Business School Press.

Huang, K.-P., Wang, C.-H., Tseng, M.-C., \& Wang, K. (2010). A study on entrepreneurial orientation and resource acquisition: the effects of social capital. African Journal of Business Management, 4(15), 3226-3231. 
Hung, R. Y. Y., Lien, B. Y.-H., Yang, B., Wu, C.-M., \& Kuo, Y.-M. (2011). Impact of TQM and organizational learning on innovation performance in the high-tech industry. . International Business Review, 20(2), 213-225.

Ibeh, K., \& Young, S. (2001). Exporting as an entrepreneurial act: an empirical study of Nigerian firms. Europ. J. Market, 35(5/6), 566-586.

Idris, A. (2012). Globalisation and socio-economic development in Malaysia: whither small businesses? . Asian Journal of Business and Accountancy, 5(1), 109-127.

Jaafar, M., A.R Abdul-Aziz, A. R., Maideen, S. A., \& Mohd, S. Z. (2011). Entrepreneurship in the tourism industry: Issues in developing countries. International Journal of Hospitality Management, 30(4), 827-835. doi:10.1016/j.ijhm.2011.01.003

Jamak, A. B. S. A., Salleh, R., Sivapalan, S., \& Abdullah, A. (2012). Micro business enterprise of Bumiputera Malays, Malaysia African Journal of Business Management, 6(22), 6504-6510.

Karagozoglu, N., \& Lindell, M. (1998). Internationalization of small and medium-sized technologybased firms: An exploratory study. Journal of Small Business Management, 36(1), 44-59.

Knight, G. A. G., \& Cavusgil, S. T. (2004). Innovation, Organizational Capabilities and the BornGlobal firm. Journal of International Business Studies, 35(2), 124-141.

Matenge, T. (2011). Small Firm Internationalization - A Developing Country Perspective. International Journal of Business Administration, 2(4), 103-111.

MATRADE. (2017). Export contribution of SMEs still low. The Sun Daily.

Miller, D. (1983). The correlates of entrepreneurship in three types of firms. Management Science, 29(7), 770-791.

Mintzberg, H. (1973). The Nature of Managerial Work. New York: Harper \& Row.

Mtigwe, B. (2005). The Entrepreneurial Firm Internationalization Process in the Southern African Context: A Comparative Approach (Vol. 11).

Peng, M. W., \& Delios, A. (2006). What Determines the Scope of the Firm over Time and around the World? An Asia Pacific Perspective. . Asia Pacific Journal of Management, 23(4), 385-405.

Ringle, C. M., Sarstedt, M., \& Straub, D. W. (2012). A Critical Look at the Use of PLS-SEM. MIS Quarterly, 36(1), iii-xiv.

Root, F. (1994). Entry strategies for International Markets. New York: Jossey-Bass Book.

Saixing, Z., Xie, X. M., Tam, C. M., \& Wan, T. W. (2009). Relationships between business factors and performance in internationalisation: an empirical study in China. Management Decision, 47(2), 308-329.

Scarborough, N. M. (2012). Effective small business management: An entrepreneurial approach, (Vol. 10). New Jersey: Prentice Hall.

Shamsuddoha, A. K., Ali, M. Y., \& Ndubisi, N. O. (2009). Impact of government export assistance on internationalization of SMEs from developing nations. Journal of Enterprise Information Management, 22(4), 408-422.

Smallbone, D., \& Welter, F. (2001). The Distinctiveness of Entrepreneurship in Transition Economies. Small Business Economics, 16(4), 249-262.

SMECorp. (2012). SME Annual Report 2011/12. Retrieved from Kuala Lumpur:

Spencer, J., \& Gomez, C. (2004). The relationship among national institutional structures, economic factors, and domestic entrepreneurial activity: a multicountry study. Journal of Business Research, 57(10), 1098-1107.

Stam, E. (2015). Entrepreneurial Ecosystems and Regional Policy: A Sympathetic Critique. European Planning Studies, 23(9), 1759-1769.

Tambunan, T. (2008). SME development, economic growth, and government intervention in a developing country: The Indonesian story (Vol. 6). 
Terjesen, S., \& Elam, A. (2009). Transnational Entrepreneurs' Venture Internationalization Strategies:. A Practice Theory Approach. Entrepreneurship Theory and Practice, 33(5), 10931120, 33(5), 1093-1120.

Tsang, E. W. K. (2002). Learning from overseas venturing experience: The case of Chinese family businesses. Journal of Business Venturing, 17(1), 21-40.

Urbach, N., \& Ahlemann, F. (2010). Structural Equation Modeling in Information Systems Research Using Partial Least Squares. Journal of Information Technology Theory and Application, 11(2), 5-40.

Vinzi, V. E., Chin, W. W., Henseler, J., \& Wang, H. (2010). Handbook of Partial Least Squares Concepts, Methods and Applications. Verlag Berlin Heidelberg: Springer.

Zahra, S., Hayton, J., \& Salvato, C. (2004). Entrepreneurship in family vs. Non-Family firms: A Resource-Based analysis of the effect of organizational culture. Entrepreneurship theory and Practice, 28(4), 363-381.

Zahra, S. A., \& George, G. (2002). Absorptive Capacity: A Review, Reconceptualization, and Extension. The Academy of Management Review, 27(2), 185-203.

Zahra, S. A., Korri, J. S., \& Yu, J. (2005). Cognition and international entrepreneurship: Implications for research on international opportunity recognition and exploitation. International Business Review, 14(2), 129-146.

Zainol, F. A., \& Ayadurai, S. (2011). Entrepreneurial Orientation and Firm Performance: The Role of Personality Traits in Malay Family Firms in Malaysia. International Journal of Business and Social Science, 2(1), 59-72. 
INTERNATIONAL JOURNAL OF ACADEMIC RESEARCH IN BUSINESS AND SOCIAL SCIENCES

Vol. 8, No. 7, July 2018, E-ISSN: 2222-6990 (C) 2018 HRMARS

\section{Appendix 1}

Table 4.3: Discriminant Validity of Construct

\begin{tabular}{l|ccccccccc}
\hline & & & FUN & & \multicolumn{1}{c}{ NON } & & & \\
& CONT & FINA & D & INNO & INTN & F & POLI & PROA & RISK \\
\hline CON & & & & & & & & & \\
T & $\mathbf{0 . 8 7 8}$ & & & & & & & & \\
FINA & 0.357 & $\mathbf{0 . 9 3 9}$ & & & & & & & \\
FUN & & & & & & & & & \\
D & 0.734 & 0.303 & $\mathbf{0 . 8 6 8}$ & & & & & & \\
INNO & 0.155 & 0.156 & 0.221 & $\mathbf{0 . 7 2 1}$ & & & & & \\
& & & & - & & & & & \\
INTN & 0.208 & 0.324 & 0.219 & 0.021 & $\mathbf{0 . 8 1 5}$ & & & & \\
NON & & & & & & & & & \\
F & 0.309 & 0.274 & 0.343 & 0.401 & 0.219 & $\mathbf{0 . 8 4 2}$ & & & \\
POLI & 0.826 & 0.357 & 0.833 & 0.183 & 0.229 & 0.332 & $\mathbf{0 . 8 5 2}$ & & \\
PROA & 0.207 & 0.236 & 0.246 & 0.552 & 0.093 & 0.332 & 0.270 & $\mathbf{0 . 8 1 4}$ & \\
RISK & 0.199 & 0.280 & 0.272 & 0.699 & 0.065 & 0.365 & 0.239 & 0.687 & $\mathbf{0 . 7 6 2}$ \\
\hline
\end{tabular}

Notes: CONT (Contract); FINA (Financial Performance); FUND (Funding); INNO (Innovation); INTN (Internationalization); NONF (Non-Financial Performance); POLI (Policy); PROA (Proactive); RISK (Risk Taking)

\section{Appendix 2}

Table 4.4: Path Coefficient (Without Mediating Variable)

\begin{tabular}{cccccc}
\hline & Path & $\begin{array}{c}\text { Path } \\
\text { Coefficient }\end{array}$ & $\begin{array}{c}\text { Std } \\
\text { Error }\end{array}$ & T-Value & Decision \\
\hline H1 & $\begin{array}{c}\text { EO } \rightarrow \\
\text { INT }\end{array}$ & 0.035 & 0.102 & 0.324 & $\begin{array}{c}\text { Not } \\
\text { Supported }\end{array}$ \\
H2 & $\begin{array}{c}\text { GS } \rightarrow \\
\text { INT }\end{array}$ & 0.253 & 0.072 & $3.524^{* * *}$ & Supported \\
H3 & $\begin{array}{c}\text { EO } \rightarrow \\
\text { FP }\end{array}$ & 0.214 & 0.074 & $2.817^{* * *}$ & Supported \\
H4 & $\begin{array}{c}\text { GS } \rightarrow \\
\text { FP }\end{array}$ & 0.244 & 0.068 & $3.656^{* * *}$ & Supported \\
H5 & $\begin{array}{c}\text { INT } \rightarrow \\
\text { FP }\end{array}$ & 0.239 & 0.050 & $4.894^{* * *}$ & Supported \\
\hline$* * *$ &
\end{tabular}

Notes: EO (Entrepreneurial Orientation); GS (Government Support); INT (Internationalization); FP (Firm Performance)

\section{Appendix 3}

Table 4.6: Hypotheses testing for indirect effect 
INTERNATIONAL JOURNAL OF ACADEMIC RESEARCH IN BUSINESS AND SOCIAL SCIENCES Vol. 8, No. 7, July 2018, E-ISSN: 2222-6990 @ 2018 HRMARS

\begin{tabular}{|c|c|c|c|c|c|c|c|c|}
\hline \multirow{2}{*}{\multicolumn{2}{|c|}{$\begin{array}{c}\text { Mediating } \\
\text { Hypotheses }\end{array}$}} & \multirow{2}{*}{$\begin{array}{c}\text { Indirect } \\
\text { Effect }\end{array}$} & \multirow{2}{*}{\multicolumn{2}{|c|}{$\begin{array}{c}\begin{array}{c}\text { Total } \\
\text { Effect }\end{array} \\
\left(a^{*} b\right)+c^{\prime}\end{array}$}} & & & & \\
\hline & & & & & & & & \\
\hline $\mathrm{H} 6$ & $\begin{array}{c}\mathrm{EO} \rightarrow \mathrm{I} \\
\mathrm{NT} \rightarrow \mathrm{F} \\
\mathrm{P}\end{array}$ & 0.008 & $\begin{array}{c}0.00 \\
9\end{array}$ & 0.017 & $\begin{array}{c}0.02 \\
5\end{array}$ & 0.322 & - & $\begin{array}{c}\text { Not } \\
\text { Supporte } \\
\text { d }\end{array}$ \\
\hline $\mathrm{H} 7$ & $\begin{array}{c}\mathrm{GS} \rightarrow \mathrm{I} \\
\mathrm{NT} \rightarrow \mathrm{F} \\
\mathrm{P}\end{array}$ & 0.060 & $\begin{array}{c}0.06 \\
0\end{array}$ & 0.120 & $\begin{array}{c}0.02 \\
2\end{array}$ & $\begin{array}{c}2.887^{*} \\
* *\end{array}$ & $50 \%$ & $\begin{array}{l}\text { Supporte } \\
\text { d Partial } \\
\text { Mediatio } \\
n\end{array}$ \\
\hline
\end{tabular}

Notes: EO (Entrepreneurial Orientation); GS (Government Support); INT (Internationalization); FP (Firm Performance) 